\title{
Managing Strategic Changes Through DEEP Reforms: A View from the Perspective of U.S.-Armenia "Smart Power" Cooperation
}

\author{
Hayk Kotanjian *
}

Education is a systematic process of forming the fundamental ability to think analytically, incorporating both basic and specialized knowledge. Therefore, in the armed forces of leading countries of the world, the field of military education and personnel management is regarded as a primary factor for ensuring the efficiency of the defense security system and the combat capability of the military.

Defense education reforms are a significant part of the overall reforms being implemented in the defense security sector in Armenia that are helping bring both more credibility and accountability into the Armenian Armed Forces and the National Security System on the whole. The importance of defense education has grown significantly within recent years due to the introduction of sophisticated new armament systems. Current military standards demand a new level of requirements for both soldiers and officers, and military professional education is one of the most important tools to help prepare highly qualified personnel who will be capable of implementing different tasks in the rapidly changing atmosphere of the modern battlefield.

The cause and the essence of these innovations are not only due to hard power subsystem dynamics, but also require accepting the fundamentally new orientation in thinking about security that is not exclusively based on threat assessments and a presumed hard power response, as was the case in the past. Over the past decade, after the Prague NATO Summit, Armenia has employed comparative analysis and innovative decision making to smoothly turn its defense security thinking toward a goal-oriented approach that synthesizes both soft and hard security dimensions within one holistic "smart power"-oriented defense security policymaking system. The other important dimension of these improvements is a gradual transition from an obsolete "apparatchik" mode of Stalinist-style military governance of the Ministry of Defense to a modern leadership and management culture characterized by the redistribution of powers between defensepolicy institutions and military bodies and the delegation of power and duties to lower tiers in the hierarchy.

In the United States, the system of professional military education (PME) must meet certain basic requirements, namely that it should be comprehensive, systemic, consistent, realistic, effective, and unanimous in concept, terms, goals, challenges, and opportunities. The U.S. system is familiar to me, due to my five and a half years of Defense, Army, Air Force, and Navy Attaché service as well as having

\footnotetext{
Dr. Hayk Kotanjian is a Major-General in the Armenian Armed Forces and a founder head of the Institute for National Strategic Studies in the Armenian Ministry of Defense. He has served as a visiting professor at the Institute for National Strategic Studies at the U.S. National Defense University, and as an Academic-Expert Board member of the CSTO.
} 
held academic fellowships at the Defense Language Institute in San Antonio, Harvard University's National Security Program, the National Defense University, RAND, and the Marshall Center for Security Studies. PME training places constant tension on the mind, will, and body, giving great attention to physical fitness and its major role in service activity of all categories of personnel.

\section{The Early Stages of Armenia's Defense Education Sector Development}

The formation of Armenia's armed forces coincided with what was probably the most difficult and stressful period of modern Armenian history: the transition from a Sovietstyle totalitarian regime to independent national statehood oriented around the values of liberal democracy. Drafting the main design of the Armenian Army simultaneously with the establishment of Armenian independent statehood became a challenge that needed to be addressed precisely, given the conditions of extreme uncertainty that characterized the dynamics of the post-Soviet system of global, regional, and national security. It was a matter of great responsibility and commitment for me to be ordered by the leadership of the newly born Ministry of Defense to develop the "Basics of Military Policy of the Republic of Armenia," published in 1992 as the first military-political national document outlining the doctrinal content and strategic caliber of an independent Armenia. ${ }^{1}$ This document became the initial framework essential to developing a national military education policy.

Additional hardships for Armenia were caused by hostilities in Nagorno-Karabakh, as well as by a blockade implemented by Azerbaijan and Turkey. In those difficult days, the ranks of the Armenian Army were by necessity filled by many patriotic people with insufficient military experience and education. It should be emphasized that during the Soviet period Armenia was the only Republic that had no defense education institution that could serve as a starting point for developing a defense education sector after the dissolution of the USSR.

Meanwhile, the Armenian leadership was well aware of the importance of defense education in the overall process of building the nation's armed forces. The Ministry of Defense launched the process of establishing defense education institutions in 1994. First, two junior officers' military schools for the army and air force were established in June and September 1994 . $^{2}$ Simultaneously, the MoD also established a special military high school with the core mission of preparing the younger generation for future service in the armed forces.

At that period of time, the military political leadership of Armenia understood quite well the difficulties that were posed by the process of creating a functional defense edu-

1 Dr. Hayk Kotanjian, "Basics of Military Policy of the Republic of Armenia: Military-Political Aspect of National Security" (in Armenian) (Yerevan: Military Policy Department, MOD Armenia, 1992).

2 See the decisions of the Armenian government adopted on 24 June 1994 and 20 September 1994, available at http://www.arlis.am/DocumentView.aspx?docid=5475 and www.arlis.am/ DocumentView.aspx?docid=5525 (in Armenian). 
cation system. One of the problems was the lack of necessary qualified specialists on different subjects, especially concerning the preparation of senior officers for the Armenian Army. One of the urgent efforts undertaken to overcome this obstacle was the development of cooperation in the defense education field with Russia, Armenia's strategic ally, which also announced its turn toward democracy in that period of time.

Russian-Armenian cooperation in the field of defense education was based on the 1997 Agreement on Friendship and Mutual Assistance between the two nations. ${ }^{3}$ Simultaneously, the first steps were launched to build contacts with NATO member states as well. In 1994, Armenia joined the NATO-led Partnership for Peace (PfP) program, which was created to enable bilateral cooperation between individual countries and NATO. It has widely been referred to as a platform aimed at bringing former Soviet republics closer to NATO. A distinguishing feature of the program lay in the opportunity it provided for Armenia to build an individual relationship with NATO, with the purpose of increasing stability and building strengthened security relationships. Later Armenia joined the PfP Planning and Review Process (PARP), which was considered the main instrument within the cooperative security framework. In the spirit of PfP, as a result of intensive bilateral consultations, Armenia launched a Western-oriented initiative of military cooperation, initially working with Greece as the first partner state from NATO. In 1996, Armenia and Greece signed cooperation agreements in the military sector and furthered this cooperation through an education-training agreement in 1998, which allowed Armenian officers to receive training in Greece's military education institutes. At that time it was a dramatically new experience for me, as a head of the Armenian MoD's International Relations and Military Cooperation Department, to launch, balance, and manage - on behalf of the Armenian Minister of Defense - this type of cooperation in the field of professional military education with both Western and post-Soviet partners. Thus, at the end of the 1990s, Armenia managed to overcome various challenges and develop a working mechanism for its defense education system as a basis for what has become a set of strategic, future-oriented reforms to professional military education carried out under the Defense Education Enhancement Program (DEEP).

\section{The Current Phase of PME Reforms}

By the beginning of the twenty-first century, Armenia had finished the first phase of building its defense education system through creating a functioning model that satisfied the minimal requirements of the armed forces. Meanwhile, it was obvious that the system remained mainly based on the old Soviet-style, hard security-oriented mindset and decision-making processes, and was thus inadequate to the new challenges in the defense security sector of the new millennium. The other core problem facing the Armenian Armed Forces was the fact that, despite the existence of two military institutions, Armenia had no capacity to deliver education for senior-level officers, and was thus obliged to send a growing number of officers to foreign defense education institutions

3 The full text of the agreement is available at http://www.parliament.am/library/erkoxm/19961998/73.pdf (in Armenian). 
(mainly to Russia). Another obstacle on the way to developing the defense education system in Armenia was the growing gap between the spheres of civil and defense education. Since the mid-1990s, Armenia had been actively involved in the process of civil education reform, seeking to introduce in Armenia the European model of secondary and higher education. More commonly known as the Bologna Process, it featured undergraduate, graduate, and post-graduate levels of higher education. At the beginning of the 2000s, almost all Armenian state and private universities were offering Bachelor's and Master's degrees to their students. The defense education system, however, remained largely untouched by these reforms, and continued to offer diplomas and partial Bachelor's degrees, with no Master's degrees in military art or military science.

The Ministry of Defense leadership was well aware of the situation, and was seeking ways to address the problem. The main directions of these policies included fostering relations in the field of defense education with NATO as well as planning the establishment of defense education institutions with core capabilities to prepare senior military officers, as well as undertaking necessary steps toward launching an interagency defense security education institution based on the model of the U.S. National Defense University (NDU). An important milestone in this process was the signing in 2005 of the first Armenia-NATO Individual Partnership Action Plan (IPAP). ${ }^{4}$ To better understand the U.S. perspective on the content of the IPAP crafted by NATO after its 2002 Prague Summit, I was sent in 2003 by the MoD leadership to the NDU NATO Staff Officers Orientation Program. After receiving this valuable experience direct from the "horse's mouth" in Washington and Brussels, Armenia's leadership made a decision to apply to the NATO IPAP.

IPAP requires the elaboration and approval of strategic-caliber defense security documents such as the National Security Strategy and the Military Doctrine. The application of the U.S. methodology for the interagency development of a National Security Strategy, and its comparative analysis with the Russian methodological principles, were done during my on-the-job training fellowship at the Institute for National Security Studies at the U.S. National Defense University in 2003-04, as was the research for my related monograph, Guidelines on Developing Armenian National Security Strategy in the Context of Regional Security Architecture. ${ }^{5}$ Under the auspices of Serzh Sargsyan, then Minister of Defense and now the incumbent President of Armenia, the interagency committee was formed under my academic supervision to draft the first Armenian National Security Strategy based on U.S. methodology acquired from the NDU. Targeted methodological assistance provided to the newly established Armenian INSS during this research-development creative process in 2005-06 by Dr. Theresa Sabonis-Helf, Professor at the U.S. National War College, was invaluable to the development of the new innovative approach to security thinking in Armenia. The Armenian National Security

4 Armenia's commitments under its Individual Partnership Action Plan with NATO can be seen at www.mil.am/files/IPAP-English.pdf.

5 Hayk Kotanjian, Guidelines on Developing Armenian National Security Strategy in the Context of Regional Security Architecture (Washington and Yerevan: SNSEE-INSS-NSOOC, NDU, 2004-05). 
Strategy serves as a methodological and intellectual foundation for furthering Western "smart power"-oriented security thinking and for pursuing reforms in Armenia's strategic defense education system.

IPAP also allowed Armenia to fully involve NATO experts in the process of elaborating the reforms of the defense education system. As John Berry, one of the leaders of the DEEP process, wrote on this matter:

The NATO Consortium Working Group focused on three elements of partner PME: (1) curricula that respond to the education and training needs of modern armed forces; (2) teaching and learning methods that match best practices in use in the Western defense education and training institutions, and (3) faculty and institutional development and mentoring through sustained engagement over time. For each participating partner country (Armenia, Azerbaijan, Georgia, Kazakhstan, and Moldova), the Working Group has established Defense Education Enhancement Program (DEEP), composed of U.S. and NATO defense educators. Each DEEP strives to respond to validated, demand-driven requirements from the partner nation... [including Armenia]. ${ }^{6}$

The first NATO expert group arrived in Yerevan in Spring 2008. At the beginning of 2009 , the initial defense education reform road map was agreed to with NATO specialists. The road map emphasized the importance of introducing Bologna Process standards into the defense education system with undergraduate, graduate, and post-graduate education; improvement of non-commissioned officers (NCO) preparation courses; elaboration of command and chief courses, with a mid-term goal of establishing a Command and Chief Academy; establishment of an interagency strategic-level defense education institution based on the U.S. National Defense University model through the transformation of the Armenian Institute for National Strategic Studies; and the introduction of an Advanced Distributed Learning system in the sphere of defense education.

Since 2009 the Armenian Ministry of Defense has maintained strong cooperation with a NATO Defense Education Enhancement Program Team. Over the last three years a DEEP team under the academic supervision of Dr. Jim Barrett has often been present in the Armenian MoD dealing with different aspects of defense education reform. This team contributed to the process of developing a course for junior officer staff, and also provided invaluable input to the development of goals, objectives, and curriculum for the senior officer course, which is scheduled to launch in 2013. Significant expertise in the field of strategic change management in educational systems was brought to the DEEP team through the involvement of Dr. Jim Keagle from the U.S. National Defense University. He made an important contribution to the DEEP effort by advising the project of transforming the Armenian INSS into Armenia's NDU, as well as through engaging the expertise of the U.S. Army's Command and General Staff College on curriculum and faculty development in the field of military decision making.

One of the main aspects of the DEEP team's activities in Armenia was its involvement in the process of developing the military education reform concept. In 2009-11,

6 John Berry, "PfP Consortium of Defense Academies and Security Studies Institutes Annual Report 2011," available at www.scribd.com/doc/101738262/1/John-Berry. 
the DEEP team cultivated close cooperation with Ministry of Defense leadership, including the Defense Minister Dr. Seyran Ohanyan and First Deputy Minister David Tonoyan.

In March 2012, the Armenian Government approved the concept of military education reforms as well as an action plan to implement the concrete programs put forward in the concept. ${ }^{7}$ The action plan envisaged reorganization of both the army and air force institutes, establishment of a Command and Chief Academy, and the launch of the process of transforming the Armenian Institute for National Strategic Studies into the Armenian NDU in 2013.

\section{The Armenian NDU Project}

The Armenian NDU Project is one of the main pillars of the set of proposed reforms of the Armenian defense education system, and perhaps the most ambitious. The Armenian NDU will be established through the transformation of the current Institute for National Strategic Studies. It should be emphasized that the Armenian INSS project itself was elaborated and defended at the U.S. INSS academic board during my on-the-job training at the INSS (which was part of my fellowship program at the U.S. NDU in 2002-03), with the long-term intention of the MoD's leadership to transfer it to an Armenian NDU based on the U.S. model. Since its inception in 2005, Armenia's INSS has been the intellectual as well as organizational powerhouse for the development of the nation's two main strategic documents: the Armenian National Security Strategy and its Military Doctrine. INSS is the only state think tank in Armenia dealing with regional security issues and elaborating both classified and non-classified policy papers with strategic evaluations and recommendations for the Armenian military-political leadership. INSS also publishes two quarterlies-Armenian Defense, as well its strategic studies supplement Working Papers - which often draw on intellectual resources from other Armenian agencies as well as experts from Armenian universities and the National Academy of Sciences. The INSS has already brought the Western culture of interagency cooperation into the process of policy drafting by steering the interagency commission that has been put in place for the development of the National Security Strategy.

The executive component of the Armenian NDU project was developed and reviewed during my academic research fellowship at the National Security Program led by LTG (ret.) Tad Oelstrom at Harvard University's Kennedy School of Government in Spring 2010. This program also featured two weeks of extensive discussions and research in the Fletcher School of Law and Diplomacy at Tufts University. During the Summer of 2010, the project was reviewed and further developed through close cooperation with the experts of the Armenian State Committee of Science as a part of the

7 Armenia's Military Education Concept, available at https://www.e-gov.am/u_files/file/decrees/ arc_voroshum/2012/03/MAR9-18_1.pdf (in Armenian). 
overall concept of establishing research universities in Armenia. ${ }^{8}$ The project then advanced to a full-fledged U.S. research university model at the U.S. NDU Center for Technology and National Security Policy in September-November 2011, under the supervision of Dr. James Keagle.

In November 2011, the project was presented during a special meeting in the Armenian MoD with participation of the Ministers of Defense and Science and Education, as well as James Keagle from the U.S. NDU and high-level representatives of the U.S. Embassy in Yerevan, as well as the international group of DEEP experts under the aegis of NATO. ${ }^{9}$ The amended project, with a clear road map, was introduced during a June 2012 workshop held in Yerevan that included the Minister of Defense, the Deputy Chief of Mission from the U.S. Embassy in Yerevan, and James Keagle, who had served as the academic consultant to the Armenian NDU project. ${ }^{10}$

In January 2013 the specialized workshop on the "Launch of the Armenian National Defense (Research) University Road Map" was carried out at the Armenian INSS with participation of the Armenian and American teams led by the Defense Minister Dr. Seyran Ohanyan and the Minister of Science and Education of the Republic of Armenia Dr. Armen Ashotyan, as well as the U.S. Ambassador John Heffern and Dr. James Keagle.

The project envisages the development of both the research and educational components of the university based on the notion of the combination of research and education activities. The research component will consist of three centers dealing with international and regional security studies, cyber security, and applied strategic learning. The educational component will be made up of two colleges offering ten-month Master's programs as well as interagency training programs of one to three months for mid- and high-level military and civilian officials. The INSS post-graduate school and the academic board for conferring Doctoral degrees in political science and international relations will continue its activities within the future Armenian NDU. The NDU project, targeting strategic innovative changes in the interagency system of forming a new generation of Armenia's strategic leaders, is scheduled to start in 2013.

8 Hayk Kotanjian, "Creating Strategically Oriented Interagency Environment: Senior DefenseSecurity School Model" (in Armenian, English and Russian), paper written while a Visiting Scholar at the Eurasia Security Program at Harvard University, Spring 2010. See also, Ethnic Policy of Conflicts. Basics of Military Policy and National Security of Armenia (Yerevan: Tigran Mets Publishing House and INSS, MoD, 2010), 723-62.

9 From 23-26 November, within the scope of their regular visits, the international group of experts under the aegis of NATO's DEEP initiative was in Armenia to assist in the military-educational reforms conducted in Armenia. See www.mil.am/1322144501/page/23.

10 James Keagle and Adrian Martin, "Organizing for National Security, Unification or Coordination?," Defense Horizons 60 (December 2007), available at http://www.ndu.edu/CTNSP/ docUploaded/DH_60.pdf. 


\section{Conclusions}

The Armenian defense education system has undergone tremendous changes since the creation of the independent Armenian military twenty years ago. The defense education system reforms launched in the mid-2000s facilitated the process of transformation aimed at overcoming the largely obsolete Soviet heritage and embracing modern educational methodologies and tools. In this context, the PfP Consortium's Defense Education Enhancement Program became an innovative tool for modernizing Armenia's professional military education system by making it compatible with the most effective educational models in the world and the most advanced standards and technologies of the interconnected processes of research, education, and training. 


\section{Bibliography}

Berry, John. PfP Consortium of Defense Academies and Security Studies Institutes Annual Report 2011., 2011.

Keagle, James, and Adrian Martin. "Organizing for National Security, Unification or Coordination?" Defense Horizons 60 (2007).

Kotanjian, Hayk. Basics of Military Policy of the Republic of Armenia: MilitaryPolitical Aspect of National Security (in Armenian). Yerevan: Military Policy Department, MOD Armenia, 1992.

Kotanjian, Hayk. Creating Strategically Oriented Interagency Environment: Senior Defense-Security School Model. Eurasia Security Program at Harvard University, 2010.

Kotanjian, Hayk. Ethnic Policy of Conflicts. Basics of Military Policy and National Security of Armenia. Yerevan: Tigran Mets Publishing House and INSS, MoD, 2010. 